Nig. J. Biotech. Vol. 33 (2017) 78-82

ISSN: 01891731

Available online at

http://www.ajol.info/index.php/njb/index

and www.biotechsocietynigeria.org

DOI: https://dx.doi.org/10.4314/v33i1.11

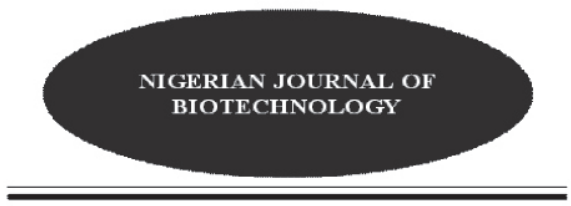

\title{
Serological detection of viruses infecting tomato and pepper in Southwest Nigeria and their distribution
}

\author{
Ayo-John, E. I. ${ }^{1}$ and Odedara, O. O. ${ }^{2}$ \\ ${ }^{1}$ Department of Crop Protection, Federal University of Agriculture, Abeokuta, PMB 2240, \\ Ogun State, Nigeria. ' ${ }^{2}$ Department of Microbiology, Federal University of Agriculture, \\ Abeokuta, PMB 2240, Ogun State, Nigeria.
}

(Received: 31:05:2011; Accepted: 4:07:2017)

\author{
Copyright resides with the authors in terms of the Creative Commons License 4.0. \\ See http://creativecommons.org/licenses/by/4.0/ \\ Condition of use: The user may copy, distribute, transmit and adapt the work, but must recognize the \\ authors and the Nigerian Journal of Biotechnology
}

\section{Abstract}

Tomato and pepper are important vegetable crops grown in Nigeria, accounting for $50 \%$ of the African production. Pathogen diversity is a prerequisite for breeding resistant cultivars, as a means of improving the production. A survey for virus disease incidence on field grown pepper and tomato was carried out in three state of southwestern part of Nigeria, and a total of 135 leaf samples comprising 58 tomato and 77 pepper leaf samples were collected from farmers' fields. Infecting viruses were detected using specific polyclonal antibodies were used in enzyme-linked immunosorbent assay (ELISA). Four viruses, Potato virus Y (PVY), Tomato mosaic virus (ToMV), Cucumber mosaic virus (CMV), and Pepper veinal mottle virus (PVMV) were detected. In tomato the distribution of viruses was 5.2\% (CMV), 5.2\% (PVY) and 39.7\% for PVMV, respectively. Leaf samples of pepper had incidence rate of $19.5 \%, 3.9 \%$ and $67.5 \%$ for CMV, ToMV and PVMV respectively. TSWV and TYLCV were not detected in any of the samples tested. The most prevalent virus on tomato and pepper was PVMV which was also the most prevalent virus in Osun, Ogun and Oyo States in Southwest Nigeria; similarly, CMV was detected in pepper crops in all the states surveyed and the most prevalent after PVMV in the three states. Mixed viral infections were few, PVY + PVMV occurring only in one tomato leaf sample while PVMV + CMV occurred on three pepper leaf samples. The control of aphid vectors that transmit these viruses and good sanitary practices against soil borne ToMV would minimize disease incidences and subsequent yield loss.

Keywords: Tomato, Pepper, virus distribution, PVMV, CMV, PVY.

Correspondence: eiayojohn@hotmail.com

\section{Introduction}

Tomato (Solanum lycopersicum L.), a member of the Solanaceae family, is an annual herbaceous fruiting plant and is widely cultivated in Nigeria by subsistence farmers (George, 2004). The crop is important as a source of vitamin A and C in human diet (Tukru, 2007), contains antioxidant with some anticancer properties (Ibitoye et. al., 2009) and is useful in making soups (Hill and Waller, 1999).

Pepper (Capsicum spp) belongs to the family Solanaceae. In Nigeria, Pepper is cultivated principally in south western and northern part of the country, in the northern guinea savannah and Sudan ecological zones (Erinle, 1989). However, there is a sizeable production of pepper in the rain forest and derived savannah of south western Nigeria (OpokuAsiama et al., 1987; Fajinmi, 2010). Nigeria accounts for about $50 \%$ of African production (Erinle, 1989; Fajinmi, 2006) making Nigeria the largest producer of pepper in tropical Africa. Pepper provides nutritional and financial benefits to local farmers, enhances food palatability and is also rich in vitamin C (Ali, 2006). They are consumed fresh and in a variety of processed products worldwide. They are used as condiments or spices to add flavor or pungency to food.

Many farmers have no knowledge of disease agents as such they do not incorporate management practices for disease protection. They rely on older, landrace selections which have only low levels of genetic 
disease resistance. An understanding of the viruses involved is needed in order to develop methods of virus and disease control to increase both productivity and quality of these crops. This research will provide the much needed key information for the national breeding programs that is aimed at the development of disease tolerant and/or resistant varieties for optimum production of the crops.

The ability to detect and identify viruses allows selection of pathogen-free plant material for propagation, resulting in higher productivity and quality. Of importance also is validation of economically important virus pathogens of fruit vegetable crops in southwest Nigeria. Hence the objectives were to detection of key viruses infecting tomato and pepper crops in three states of southwest Nigeria namely Ogun, Oyo and Osun states and their distribution.

\section{Materials and methods}

Survey of fields and farmlands were carried out in May, 2011. Three Local Government areas were surveyed per State (Figure. 1). Tomato and pepper plants were observed on the field for viral symptoms expression and leaf samples collected into polythene bags and kept on ice chips in a cooler where it was transported to the Biotechnology Laboratory of the Federal University of Agriculture, Abeokuta, Nigeria for sero-diagnosis. Double antibody sandwich enzyme linked immunosorbent assay (DAS-ELISA) according to Clark and Adams (1977) was used to detect the viruses in leaf samples of tomato and pepper plants. Viruses tested include Tomato yellow leaf curl virus (TYLCV), Tomato spotted wilt virus (TSWV) genus Tospovirus, Cucumber mosaic virus, (CMV) genus Cucumovirus, Tomato mosaic virus (ToMV) genus Tobamovirus, Pepper veinal mottle virus (PVMV) genus Potyvirus and Potato virus Y (PVY) genus Potyvirus.

\section{DAS-ELISA Protocol used}

Microtitre wells of ELISA plates were coated with $100 \mu$ of appropriately diluted immunoglobulin G (IgG) to each of the respective viruses under test in coating buffer containing $1.59 \mathrm{~g}$ Sodium carbonate $\left(\mathrm{Na}_{2} \mathrm{CO}_{3}\right)$ and $2.93 \mathrm{~g}$ Sodium bicarbonate $\left(\mathrm{NaHCO}_{3}\right)$ per litre, $\mathrm{pH}$ 9.6. Plates were incubated at $37^{\circ} \mathrm{C}$ for $2 \mathrm{~h}$ after which the contents were decanted and wells washed three times with single strength phosphate buffer with $0.05 \%$ tween $20(\mathrm{v} / \mathrm{v})$ (PBS-T) composed with $8.0 \mathrm{~g}$ Sodium chloride $(\mathrm{NaCl}), 0.2 \mathrm{~g}$ monobasic Potassium phosphate $\left(\mathrm{KH}_{2} \mathrm{PO}_{4}\right), 1.15 \mathrm{~g}$ dibasic Sodium phosphate $\left(\mathrm{Na}_{2} \mathrm{HPO}_{4}\right)$ and $0.2 \mathrm{~g}$ Potassium chloride $(\mathrm{KCl})$ per litre, $\mathrm{pH}$ 7.4. ELISA plates were tapped dry and $100 \mu \mathrm{l}$ aliquots of extracted sap of infected pepper and tomato leaves with negative and positive controls provided were pipetted into the wells and incubated overnight in the refrigerator at $4^{\circ} \mathrm{C}$. Contents of wells were decanted and wells washed as previously described. One hundred microlitre of appropriately diluted enzyme-labelled antibody (IgG-alkaline phosphatase) to the respective tested virus in conjugate buffer $(1.0 \mathrm{~g}$ polyvinyl pyrrolidone $[\mathrm{PVP}], 0.1 \mathrm{~g}$ egg albumin/L PBST) was added to each well and incubated at $37^{\circ} \mathrm{C}$ for $2 \mathrm{~h}$. Wells were washed and plates tapped dry before $100 \mu \mathrm{l}$ of 1 $\mathrm{mg} / \mathrm{ml}$ para-nitrophenyl phosphate dissolved in substrate buffer ( $97 \mathrm{ml}$ diethanolamine/L, $\mathrm{pH} 9.8$ ) was added per well and contents incubated at room temperature for $1 \mathrm{~h}$ and/or overnight at $4^{\circ} \mathrm{C}$, after which the spectrophotometric reading was taken using an ELISA plate reader (model MR-96, MINDRAY) at 405 $\mathrm{nm}$. Sample was considered positive when its absorbance value was two times the average value of the incorporated healthy (negative) control.

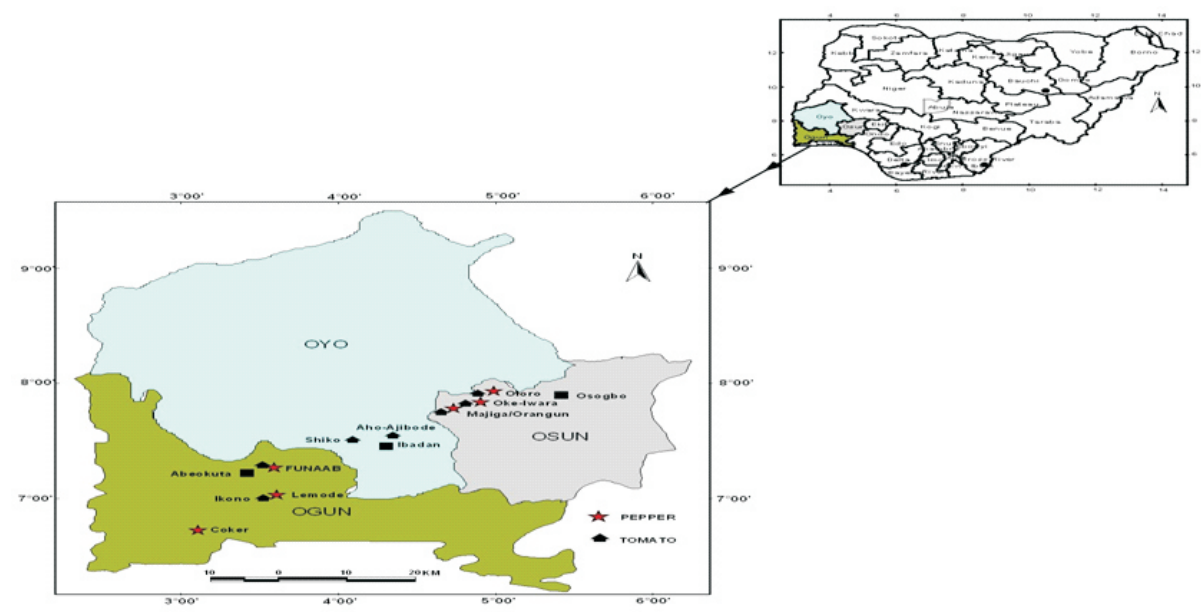

Figure 1: Surveyed areas for collection of viral-infected tomato and pepper leaf samples. 


\section{Results}

Varied symptoms were observed on pepper and tomato plants which included mottling, leaf curling, veinal chlorosis, severe mosaic and veinbanding. Out of 135 tomato and pepper leaf samples collected and indexed using 7 polyclonal antibodies, $74.8 \%$ (101 of 135) were positive. The most prevalent virus on both tomato and pepper leaves sampled was PVMV (Figure 2). It had the incidence of $55.6 \%$ (75 of 135) followed by CMV which had $13.3 \%$ (18 of 135). Three viruses, CMV, PVY and PVMV were detected in all the sampled leaf samples with incidence values of 13.3, 3.7 and 55.6 $\%$ respectively. Of all the viruses tested, TYLCV and TSWV were not detected in any of the samples tested.

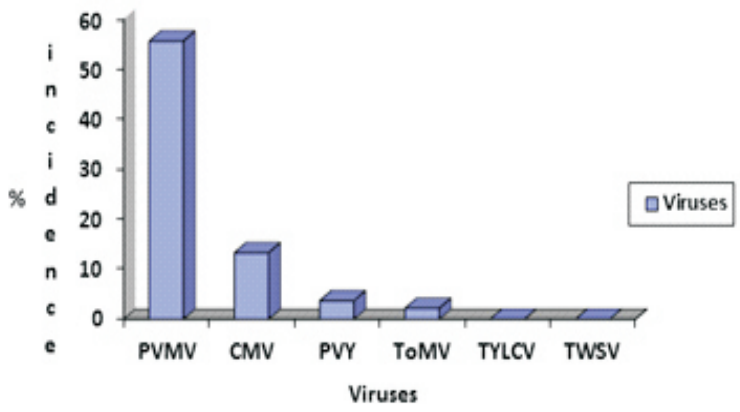

Figure 2: Overall incidence of viruses detected in leaf samples of tomato and pepper plants in three states of southwest Nigeria in 2011.

In 58 leaf samples of tomato crops indexed, PVMV was detected in 17 (29.3\%), CMV was singly detected in $3(5.2 \%)$ and PVY (5.2\%) respectively (Figure 3).

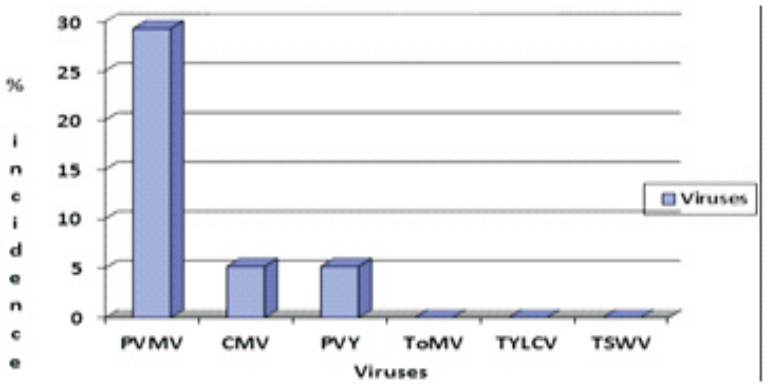

Figure 3: Virus incidence in Tomato leaf samples from three states in southwest Nigeria in 2011

Seventy-seven (77) leaf samples of pepper were collected and tested but only 72 (93.5\%) tested positive for one or two viruses. The most prevalent virus detected in pepper leaves was PVMV and it was detected in 52 (67.5\%) leaf samples of pepper followed by CMV which was detected in 15 samples (19.5\%) and ToMV in 3 samples (3.9\%) (Figure 4).
The virus PVY was detected in 2 samples (2.6\%) while TYLCV and TSWV were not detected in any of the leaf samples of pepper crops surveyed.

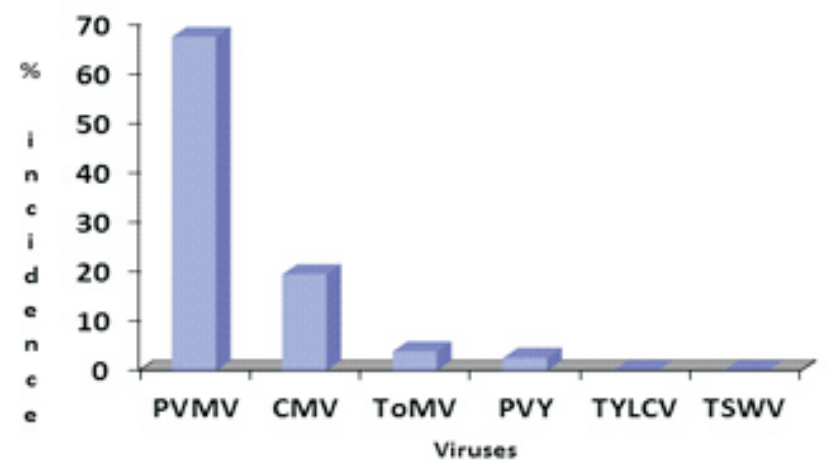

Figure 4: Virus incidence in pepper leaf samples from three states of southwest Nigeria in 2011

Distribution of viruses across the states indicated that only two viruses (CMV and PVMV) were prevalent in leaf samples collected from Ogun, Osun and Oyo states. PVY was only detected in tomato samples from Oyo and Osun states and not Ogun. ToMV was detected in leaf samples of pepper collected from Ogun state (Figure 5).

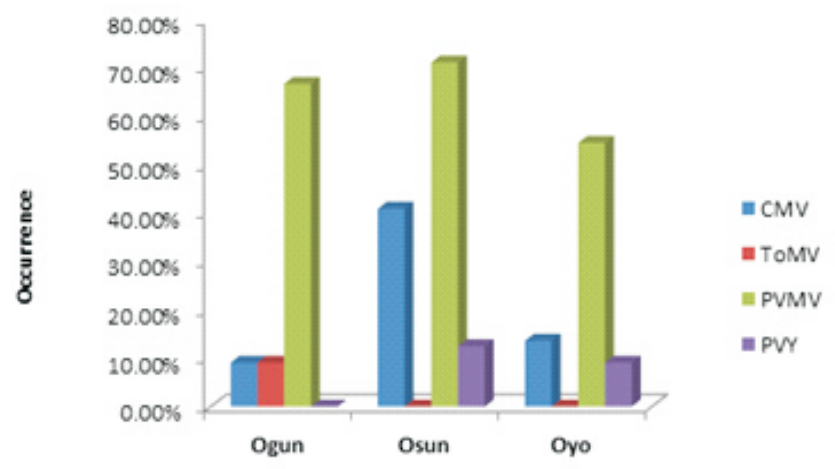

Distribution of viruses infecting tomato and pepper crops in three states of Southwest Nigeria in 2011

Mixed viral infections were few, PVY and PVMV occurred together only in one tomato leaf sample $(0.7 \%)$ while mixture of PVMV and CMV occurred on three pepper leaf samples (2.2\%).

\section{Discussion}

From the survey, it was evident that three major viruses infected tomato and pepper plants in the area surveyed during the period.

Major virus symptoms observed on tomato included mosaic, leaf curl and mottling, and the associated viruses were PVMV, PVY and CMV while on pepper the symptoms were vein banding, leaf curl and mottling, and key viruses included were PVMV, CMV and ToMV. 
The virus PVMV had been implicated in the infection of cropped pepper and tomato in Nigeria, Republic of Benin, Iran, India and Afghanistan (Arogundade et. al., 2012; Afouda et. al., 2013; Soleimani et. al., 2014; AVRDC, 2014). The virus had been found to have high frequency of occurrence in tested field leaf samples of tomato and pepper and have been found in mixed infection with other viruses such as CMV and TSWV (Soleimani et. al., 2014; Arogundade et. al., 2012; Afouda et. al., 2013). Some non-solanaceous plants that have been found infected with PVMV were Euphorbia hirta, Leucas martinensis, Combretum micranthum (Afouda et. al., 2013).

The detection of CMV in this study is in accord with the study of Sawalha, (2012) who also detected the similar virus in tomatoes in the northern districts of West Bank, Palestine. The virus was the second most dominant tomato virus during a survey in Palestine as in this study. Symptoms of CMV on pepper and tomatoes include mottling and shoestring leaf blade symptoms (Massumi et. al., 2009). The infection of CMV on tomato plants may be attributed to allate aphid species such as the green peach aphid (Myzus persicae Sulzer) and the melon aphid (Aphis gossypii Glover) (Sawalha, 2012). The virus had been reported to occur in mixed combinations with other tomato viruses such as TYLCV, PVMV, ToMV, TSWV, TMV and PVY (Sawalha, 2012, Arogundade et. al., 2012; Massumi et. al., 2009). CMV have a very broad, collective host range, infecting more than 1200 plant species in over 100 families, including fruit crops, vegetables and ornamentals, both monocots and eudicots (Palukaitis and García-Arenal, 2003; Palukaitis et. al., 1992).

Lack of virus control and continuous cropping may have led to build-up of disease problems in fields, this could partly account for high incidences in locations surveyed.

The high cost, and or non-availability, of virus-free seed would also have enhanced introduction of virus diseases into farmers' fields. Hence it is imperative for development of high yield and virus free tomato and pepper seeds for farmers in Nigeria.

The diseases caused by these viruses cause a significant limiting factor for the sustainable production of these vegetables especially for smallholder farmers of southwest Nigeria. Reduced yield losses due to virus diseases cause significant financial loss, hardship resulting to food insecurity for many farmers in Nigeria. Thus, development of effective control measures for the viruses detected is vital for stable production of quality vegetables for better income for the farmers and marketers as well as good nutritive value for the consumers.

\section{References}

Ali, M. (ed), (2006). Chili (Capsicum spp.) Food Chain Analysis: Setting Research Priorities in Asia. Shanhua, Taiwan: AVRDC- The World vegetable centre. Tech. Bull. 38. AVRDC Pub. 06, 678-253 pp.

Afouda, L.A.C., Kotchofa, R., Sare, R., Zinsou, V. and Winter, S. (2013). Occurrence and Distribution of viruses infecting tomato and pepper in Ahbori in Northern Benin. Phytoparasitica 41: 271-276.

Arogundade, O., Balogun, O.S. and Kareem, K.T. (2012). Occurrence and distribution of pepper veinal mottle virus and cucumber mosaic virus in pepper in Ibadan, Nigeria. Virol. J. 9: 79-82.

AVRDC. (2014). AVRDC 2014 Progress Report. Asian Vegetable Reasearch and Development Center, Shanhua, Taiwan

Clark, M.F. and Adams, A.N. (1977). Characteristics of the microplate method of enzyme linked immunosorbent assay for the detection of plant viruses. J. of Gen. Virol. 34: 475-483.

Erinle, I. D. (1989) Present status and prospects for increased production of tomato and pepper in Nigeria In AVEDC Ed. Proc. Inter. I Symp. Integrated management practices 536-547. Taiwan.

Fajinmi, A. A (2006). The incidence, spread and possible control strategies of Pepper veinal mottle Potyvirus (PVMV) disease on pepper (Capsicum annuum.L.) in Nigeria. Ph. $D$ thesis, University of Ibadan, Ibadan, Oyo State, Nigeria.

Fajinmi A. A. (2010). Agro-ecological incidence and severity of Pepper veinal mottle virus, genus Potyvirus, family Potyviridae, on cultivated pepper (Capsicum annuum L.) in Nigeria. 21st International Conference on Virus and other Graft Transmissible Diseases of Fruit Crops, Julius-Kühn-Archi. 427: 314 - 322.

George, A., (2004). Horticultural principles and practices. Prentice of India private limited.

Hill, D.S. and Waller, J.M. (1999). Pests and Diseases of Tropical Crops. Longman Group Limited, UK p. 432.

Ibitoye, D.O., Akin-Idowu P.E. and Ademoyegun, O.T. (2009). Agronomic and Lycopene Evaluation in 
tomato (Lycopersicon lycopersicum Mill.) As a Function of Genotype. WJAS 5: 892-895

Massumi, H., Shaabanian, M., Pour, A.H., Heydarnejad, J. and Rahimian, H. (2009). Incidence of Viruses infecting Tomato and their natural hosts in the southeast and Central Regions of Iran. Plant Dis. 93: 67-72.

Oetting, R. and Yunis, H. (2004). Field Guide to Common Insects, Mites and Diseases of Greenhouse Grown Sweet Peppers, Cucumbers and Tomatoes. Hakohav Press; Kfar Qari. Pp 58-79.

Opoku-Asiama, Y.A.E., Dawson, R., Adamu A. and Opeku-Asiama, M. (1987). Premature fruit drop in hot pepper (Capsicum frutescense). The Legion Agricultural Research Bulleting 2: 66-68.

Palukaitis, P. and García-Arenal, F. (2003) Cucumoviruses. Adv. Virus Res. 62:

241-323.

Palukaitis, P., Roossinck, M.J., Dietzgen, R.G. and Francki, R.I.B. (1992) Cucumber mosaic virus. Adv. Virus Res. 41: 281-348.

Sawalha, H. (2012). Quantitative effects of single and multiple infections with four viruses on tomato production. AAAB 4(18): 2804-2814

Soleimani, P., Hosseini, S. and Hosseini, A. (2014). Distribution of some viral Disease on Pepper (Capsicum annuum) plants in Dezful fields from Iran. Bulletin of Environment, Pharmacology and Life Sciences BEPLS 3: 111-114.

Tukru, H. (2007). Profitability of key crops in Fadama regions of Nigeria. International Food Policy Research Institute (IFPRI), Working, p. 12.

Zitikaite, I. and Staniulis, J. (2006). The use of RTPCR for the detection of viruses infecting Cucumber. Agron. Res. 4: 471-474. 